\title{
PENGARUH PERSEPSI KEGUNAAN DAN PERSEPSI KEMUDAHAN TERHADAP PENGGUNAAN E-FILING DAN DAMPAKNYA TERHADAP KEPATUHAN WAJIB PAJAK ORANG PRIBADI PADA KPP PRATAMA GAMBIR TIGA (SURVEI PADA KPP PRATAMA GAMBIR TIGA PERIODE APRIL-JULI 2017)
}

\author{
Kristiani Natalia $^{1}$, Arles Parulian Ompusunggu ${ }^{2}$, Jonathan Sarwono ${ }^{3}$ \\ ${ }^{1}$ Fakultas Ekonomi Universitas Tarumanagara Jakarta \\ Email: kristiani_jap@yahoo.com \\ ${ }^{2}$ Fakultas Ekonomi Universitas Tarumanagara Jakarta \\ Email: apo_sunggu@yahoo.co.id \\ ${ }^{3}$ Fakultas Ekonomi Universitas Tarumanagara Jakarta \\ Email: jonathan@upi.edu
}

\begin{abstract}
ABSTRAK
Penelitian ini bertujuan untuk menguji Pengaruh Persepsi Kegunaan, Persepsi Kemudahan terhadap Penggunaan efiling dan dampaknya terhadap Kepatuhan Wajib Pajak. Penelitian ini menggunakan pendekatan kuantitatif dengan desain descrptive.Pengambilan data dilakukan dengan teknik random sampling. Data yang digunakan adalah data primer yang diperoleh dengan menggunakan kuesioner. Subyek penelitian ini adalah wajib pajak individu yang terdaftar di KPP Pratama Gambir Tiga. Sampel yang digunakan dalam penelitian ini berjumlah 390 responden. Teknik analisis data menggunakan analisis jalur dengan dibantu menggunakan program SPSS versi 22.0 Hasil dari penelitian ini adalah Persepsi Kegunaan berpengaruh positif dan signifikan terhadap penggunaan $e$-filing, Persepsi Kemudahan berpengaruh positif dan signifikan terhadap penggunaan $e$-filing, Penggunaan $e$-filing berpengaruh positif dan signifikan terhadap kepatuhan wajib, Persepsi Kegunaan berpengaruh positif dan signifikan terhadap kepatuhan wajib, Persepsi Kemudahan berpengaruh positif dan signifikan terhadap kepatuhan wajib pajak.
\end{abstract}

Kata kunci : Persepsi Kegunaan,Persepsi Kemudahan, Penggunaan e-filing, Kepatuhan Wajib Pajak OP.

\section{ABSTRACT}

This research aims to examine the Effect of Perceived usefulness, Perceived Ease of Use e-filing and its impact on Taxpayer Compliance. This research uses quantitative approach with descriptive design. The data were collected using a random sampling technique. The data used are the primary data obtained by using the questionnaire. The subjects of this study are individual taxpayers registered in KPP Pratama Gambir Tiga. The sample used in this study is as much as 390 respondents. The procedure of analyisis used is Path Analysis and the calculation is done using SPSS 22. The research results show all hypotheses are accepted. Perceived usefulness has positive and significant effect on the use of e-filing. Perceived ease of use has positive and significant effect on the use of e-filing, Perceived usefulness has positive and significant effect on tax compliance. Perceived ease of use has positive and significant effect on tax compliance. Use of e-filing has positive and significant effect on tax compliance.

Keywords: Perceived usefulness, Perceived ease of use, e-filing,Tax Compliance

\section{PENDAHULUAN}

\section{Latar Belakang}

Seiring dengan era perkembangan teknologi yang sangat pesat, sistem pelaporan pajak seharusnya semakin efektif dan efisien sehingga wajib pajak mudah untuk mengaplikasikannya. Sebagaimana upaya peningkatkan pelayanan kepada wajib pajak dalam pelaporan perpajakannya yang dikembangkan oleh Direktur Jendral Pajak (DJP) yaitu sistem $e$-filing sesuai Peraturan Dirjen Pajak NOMOR PER-01/PJ/2017 yang dilakukan secara online dan realtime diharapkan dapat meningkatkan jumlah Wajib Pajak terdaftar yang melaporkan SPT Perpajakannya (Noviandini,2012). Wajib Pajak tidak perlu mengantri dan lebih mudah menjalankan kewajibannya sebagai wajib pajak tanpa harus mengantri di Kantor-kantor Pelayanan Pajak 
sehingga dirasakan lebih efektif dan efisien. Selain itu, sosialisasi mengenai $e$-filing terhadap Wajib Pajak masih belum maksimal dan berkelanjutan. Padahal pelaporan SPT secara komputerisasi memiliki manfaat yang lebih besar bagi Wajib Pajak dan Direktorat Jenderal Pajak (DJP). Tetapi e-filing masih belum dikenal secara menyeluruh oleh wajib pajak, sehingga wajib pajak yang menggunakan $e$-filing masih minim (Petrus,2014).

Tabel 1.1 Persentase Pengguna $e$-filing (Data Nasional)

Sumber : Kanwil Jakarta Pusat (2016)

\begin{tabular}{|l|c|c|c|c|c|}
\hline \multirow{2}{*}{ Jenis Pelaporan } & \multicolumn{5}{|c|}{ Tahun } \\
\cline { 2 - 6 } & $\mathbf{2 0 1 2}$ & $\mathbf{2 0 1 3}$ & $\mathbf{2 0 1 4}$ & $\mathbf{2 0 1 5}$ & $\mathbf{2 0 1 6}$ \\
\hline E-filing & $0 \%$ & $0,49 \%$ & $9,67 \%$ & $17,02 \%$ & $92,91 \%$ \\
\hline
\end{tabular}

Pengguna e-filing pada tahun 2013 sudah mulai meningkat dari tahun sebelumnya, terutama ditahun 2016 yang meningkat menjadi 92,91\%. Dengan adanya peningkatan penggunaan e-filing diharapkan kepatuhan wajib pajak juga akan meningkat.

Tabel 1.1 Persentase Tingkat Kepatuhan WP OP

Sumber : KPP Pratama Gambir Tiga (2016)

\begin{tabular}{|l|c|c|c|c|c|}
\hline \multirow{2}{*}{ Jenis Pelaporan } & \multicolumn{5}{|c|}{ Tahun } \\
\cline { 2 - 6 } & $\mathbf{2 0 1 2}$ & $\mathbf{2 0 1 3}$ & $\mathbf{2 0 1 4}$ & $\mathbf{2 0 1 5}$ & $\mathbf{2 0 1 6}$ \\
\hline E-filing & $50 \%$ & $62 \%$ & $60 \%$ & $64 \%$ & $66 \%$ \\
\hline
\end{tabular}

Penelitian yang dilakukan di KPP Pratama Gambir Tiga menunjukkan bahwa walaupun tingkat penggunaan e-filing meningkat secara nasional tetapi tingkat kepatuhan WP masih belum maksimal pada tahun 2016 sebesar 66\% , Seharusnya seiring dengan hasil pemelitian Lai dan Fatt (2008) sistem e-filing tersebut mampu meningkatkan kepatuhan terhadap pelaporan pajak. Kepatuhan dalam menggunakan e-filing yang diikuti dengan peran aktif dari WP sangat berpengaruh dalam menunjang tercapainya target penerimaan pajak. Pemahaman mengenai perpajakan serta kepatuhan masyarakat sebagai WP yang diikuti dengan sosialisasi mengenai $e$ filing dalam pelaporan dan penyampaian SPT secara online dapat memberikan manfaat bagi WP maupun Dirjen Pajak. Sehingga pemahaman penggunaan serta kemudahan e-filing sangatlah mempengaruhi kepatuhan WP. Dalam hal ini Pemahaman merupakan niat perilaku dan kepatuhan WP diperlukan oleh Dirjen Pajak untuk meningkatkan kualitas dalam penggunaan $e$ filing. Selain itu, Menurut Desmayanti (2012) Kemudahan dalam menggunakan sistem akan mempengaruhi penggunaan e-filing.

Menurut Kolompoy et,al (2015) penggunaan e-filing merupakan salah satu teori sistem teknologi informasi yaitu Technology Acceptance Model (TAM). TAM memiliki teori yang sangat berpengaruh terhadap penggunaan sistem teknologi informasi. Niat seseorang merupakan penentu utama dalam menggunakan sistem atau tidak. Disamping itu TAM juga masih memiliki faktor-faktor seperti persepsi kegunaan (perceived usefulness) yang merupakan kepercayaan seseorang dalam menggunakan sistem, serta kinerja seseorang juga dapat meningkat. Persepsi kemudahan dalam menggunakan (perceived ease of use) adalah dimana pengguna yakin dan percaya dengan menggunakan sistem adalah mudah untuk dipelajari dan dilaksanakan.

Penggunaan $e$-filing merupakan suatu proses di mana wajib pajak menggunakan sistem $e$-filing untuk melaporkan SPT secara online. e-filing diciptakan dengan tujuan memberi keuntungan dan kemudahan bagi pihak Direktorat Jenderal Pajak dan wajib pajak dalam pelaporan SPT. Menurut Claudia (2015) Dengan adanya e-filing wajib pajak mendapatkan keuntungan yaitu 
efisiensi dan efektivitas dalam melakukan proses pelaporan SPT tahunan tanpa perlu mengkhawatirkan jam kerja operasional kantor pajak karena wajib pajak dapat menggunakan $e$ filing tanpa perlu datang ke kantor pajak. Menurut Oktavia (2013) pengaruh penggunaan sistem e-filing berpengaruh signifikan terhadap tingkat kepatuhan wajib pajak. Dapat di artikan bahwa semakin baik Peggunaann Sistem e-filing maka Tingkat Kepatuhan Wajib Pajak juga akan semakin baik.

Tujuan Penelitian ini adalah sebagai berikut:

1. Untuk mengetahui hubungan antara Persepsi kegunaan dan penggunaan $e$-filing;

2. Untuk mengetahui hubungan antara Persepsi Kemudahan dan penggunaan e-filing;

3. Untuk mengetahui hubungan antara Penggunaan e-filing dan Kepatuhan Wajib Pajak;

\section{Kajian Teori}

Teori yang relevan dengan penggunaan suatu teknologi informasi disebut Technology Acceptance Model (TAM) yang awalnya dikembangkan Davis (1989) yang merupakan salah satu model yang paling banyak digunakan dalam menerangkan dan memprediksi perilaku pengguna teknologi informasi. Model TAM yang diadopsi dari model The Theory of Reasoned Action (TRA), dikembangkan oleh Fishbe dan Ajzen (1975) dengan persepsi seseorang terhadap suatu hal akan menentukan sikap dan perilaku orang tersebut. Model ini mampu memprediksi penerimaan pengguna terhadap teknologi berdasarkan dua variabel, yaitu persepsi kegunaan (perceived usefulness) dan persepsi kemudahan penggunaan (perceived ease of use). Persepsi kegunaan (perceived usefulness) didefinisikan sebagai tingkat kepercayaan pengguna bahwa dengan menggunakan sistem, maka akan dapat meningkatkan kinerja pengguna tersebut. Sedangkan persepsi kemudahan penggunaan (perceived ease of use) didefinisikan sebagai tingkat kepercayaan pengguna bahwa sistem dapat digunakan dengan mudah dan dapat dipelajari sendiri. Berdasarkan penjelasan di atas diketahui bahwa kedua variabel Technology Acceptance Model (TAM) tersebut dapat menjelaskan aspek keperilakuan pengguna bahwa alasan pengguna dalam melihat manfaat dan kemudahan penggunaan teknologi informasi menyebabkan tindakan pengguna tersebut dapat menerima penggunaan teknologi informasi.

Sehingga bisa dikatakan bahwa TAM merupakan suatu model analisis untuk mengetahui perilaku pengguna akan penerimaan teknologi. Menurut Fatmawati (2015) Maksudnya yaitu TAM merupakan suatu teori sistem informasi yang modelnya bagaimana pengguna datang untuk menerima dan menggunakan teknologi. Melalui TAM, asumsinya pada saat pengguna akan menggunakan sistem informasi yang baru maka ada 2(dua) faktor yang mempengaruhinya, yaitu:

a. Persepsi Kemudahan Penggunaan (Ease of Use Perceived)

Dalam Davis (1989) disebutkan bahwa "ease" artinya "freedom from difficulty or great effort". Selanjutnya "ease to use perceived"didefinisikan "the degree to which a person believes that using a particular system would be free of effort". Jika diaplikasikan untuk sistem informasi, maka maksudnya pengguna meyakini kalau sistem informasi tersebut mudah dalam penggunaannya sehingga tidak memerlukan usaha keras dan akan terbebas dari kesulitan. Hal ini mencakup kemudahan penggunaan sistem informasi sesuai dengan keinginan penggunanya. Hasil penelitian Davis (1989) menunjukkan jika persepsi kemudahan dapat menjelaskan alasan pengguna untuk menggunakan sistem dan dapat menjelaskan kalau sistem yang baru dapat diterima oleh pengguna.

b. Persepsi Kegunaan (Usefulness Perceived) 
Dalam Davis (1989) disebutkan bahwa "the degree to which a person believes that using a particular system would enhance his or her job performance." Hal ini dimaksudkan bahwa pengguna percaya bahwa dengan menggunakan sistem informasi perpustakaan tersebut akan meningkatkan kinerjanya. Hal ini menggambarkan manfaat sistem dari penggunanya yang berkaitan dengan berbagai aspek. Jadi dalam persepsi kegunaan ini membentuk suatu kepercayaan untuk pengambilan keputusan apakah jadi menggunakan sistem informasi atau tidak. Asumsinya jika pengguna mempercayai kalau sistem tersebut berguna maka tentu akan menggunakannya, tetapi sebaliknya jika tidak percaya tidak akan menggunakannya kembali

Menurut Desmayanti (2012) Sistem dan teknologi informasi terdiri dari aspek perilaku karena perkembangan sistem yang terkait dengan masalah individu dan organisasional yang menggunakan sistem tersebut. Sistem informasi diterima atau tidaknya ditentukan dari sistem yang digunakan berjalan dengan baik dan mudah. Sistem informasi yang diterangkan dalam penelitian ini ialah sistem e-filing yang merupakan sebuah layanan pengiriman atau penyampaian. Jika pengguna $e$-filing memiliki pengalaman yang cukup, dalam menggunakan sistem e-filing, Pengguna akan memiliki kepercayaan diri terhadap penggunaan $e$-filing. Sehingga pengguna akan menganggap pengoperasian e-filing cukup mudah. Layanan Sistem informasi yang baik, lengkap dan berkualitas dari e-filing akan mmpengaruhi kebiasaan dan perilaku pengguna dalam meningkatkan kinerja individu dan organisasi

Menurut Laihad (2013), berdasarkan teori keperilakuan, diajukan teori yang mengatakan bahwa teknologi informasi mampu mengubah hierarki dari pengambilan keputusan pada organisasi dengan cara menekan biaya yang diperlukan oleh informasi dan memperluas distribusi informasi. Terkait dengan e-filing, dengan diciptakannya $e$-filing dalam Direktorat Jenderal Pajak (DJP) dapat merampingkan posisi-posisi dalam organisasi tersebut. Teknologi informasi mampu membawa informasi langsung dari unit-unit operasi ke atasan, dengan demikian mengurangi pekerja data yang terkait. Teknologi informasi juga dapat mendistribusikan informasi secara langsung kepada para pekerja di level yang lebih rendah. Aspek keperilakuan dalam implementasi teknologi informasi juga berkaitan dengan penerimaan pengguna terhadap teknologi informasi yang diterapkan.

Selanjutnya teori yang dikembangkan oleh Fishbein dan Ajzen (1975) yaitu Theory of Reasoned Action (TRA) yang mendasari pada psikologi sosial. Model ini menemukan hubungan antara kepercayaan, sikap, norma, tujuan, dan perilaku individual. Berdasarkan model ini, perilaku seseorang ditentukan oleh tujuan perilaku untuk melakukannya. Tujuan dari perilaku, merupakan kekuatan seseorang untuk melakukan tindakan yang ditentukan. Tujuan perilaku tersebut didefinisikan sebagai perasaan positif atau negatif mengenai suatu tindakan. Norma subjektif diartikan sebagai persepsi seseorang bahwa kebanyakan orang adalah penting baginya untuk memperkirakan perlu atau tidaknya melakukan suatu tindakan. Berkaitan dengan kemudahan penggunaan dan persepsi kemudahan dan perbaikan sistem $e$-filing maka sistim ini menjadi penting untuk persepsi pengguna dari kemudahan penggunaan sebagaimana menurut Davis (1989), Sistem e-filing menawarkan banyak manfaat bagi pembayar pajak, tetapi semua tergantung pada kemauan untuk menerima dan menggunakan tersedia layanan elektronik. Dalam beberapa tahun terakhir, perkembangan di situs web telah diperbaiki dan dihargai oleh pengguna. Persepsi kemudahan penggunaan adalah penilaian individu dari sejauh mana interaksi dengan sistem informasi spesifik atau teknologi bebas dari usaha. Menurut Bhatti.et.al (2007) kemudahan yang dirasakan dalam menggunakan sistem didefinisikan sebagai sejauh mana seorang individu percaya bahwa menggunakan teknologi tertentu akan bebas dari usaha. 
Menurut Agarwal (1999) Peneliti sebelumnya telah memberikan bukti pengaruh signifikan dirasakan khasiatnya dan persepsi kemudahan penggunaan pada niat perilaku. Selanjutnya hasil penelitian Mujiyat,dkk (2015) menekankan bahwa Persepsi kegunaan adalah tingkatan dimana pengguna percaya, bahwa dengan menggunakan teknologi atau sistem akan meningkatkan kinerja mereka dalam bekerja. Persepsi Kegunaan terhadap manfaat teknologi dapat diukur dari indikator (1) Kegunaan, meliputi beberapa dimensi ukuran yaitu menjadikan pekerjaan lebih mudah, bermanfaat, dan dapat menambah produktivitas dan (2) Efektivitas yang meliputi beberapa dimensi ukuran yaitu dapat mempertinggi efektivitas serta dapat mengembangkan kinerja pekerjaan.

Penelitian ini selanjutnya mendukung upaya meningkatkan kepatuhan Wajib pajak sebagaimana hasil penelitian Sareba (2015). Kepatuhan Wajib Pajak dibagi menjadi 2 bagian yaitu Kepatuhan materil dimana seorang wajib pajak melakukan atau memenuhi semua kewajibannya sesuai undang-undang perpajakan yang berlaku. Wajib pajak yang patuh secara material yang mengisi SPT dengan jujur, benar serta tepat waktu dalam menyampaikan SPT Tahunan. Menurut Desmayanti (2012) Persepsi Kegunaan berpengaruh signifikan positif terhadap intensitas prilaku dalam penggunaan $e$-filing,Persepsi Kemudahan berpengaruh signifikan positif terhadap dalam penggunaan $e$-filing, Kerumitan berpengaruh signifikan negatif penggunaan $e$-filing, Keamanan dan kerahasiaan berpengaruh signifikan positif terhadap penggunaan $e$-filing, Kesiapan teknologi informasi wajib pajak berpengaruh signifikan positif dalam penggunaan $e$-filing .

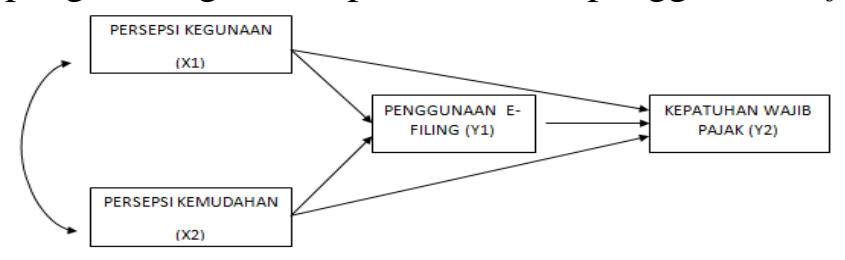

Gambar 1 : Rangka Konseptual

Sumber : Telaah Penelitian Terdahulu

Berdasarkan kerangka pemikiran yang dikembangkan dari latar belakang dan disesuaikan dengan tujuan penelitian maka didapat hipotesis sebagai berikut:

H1: Persepsi Kegunaan berpengaruh positif dan signifikan terhadap Penggunaan e-filing.

H2: Persepsi Kemudahan berpengaruh positif dan signifikan terhadap Penggunaan e-filing.

H3: Penggunaan e-filing berpengaruh positif dan signifikan terhadap kepatuhan Wajib Pajak.

H4: Persepsi Kegunaan berpengaruh positif dan signifikan terhadap Kepatuhan Wajib Pajak.

H5: Persepsi Kemudahan berpengaruh positif dan signifikan terhadap Kepatuhan Wajib Pajak. H6: Persepsi Kegunaan berpengaruh positif dan signifikan terhadap Kepatuhan Wajib pajak melalui Penggunaan e-filing.

H7: Persepsi Kemudahan berpengaruh positif dan signifikan terhadap Kepatuhan Wajib pajak melalui Penggunaan e-filing.

\section{METODE PENELITIAN}

Metode dalam penelitian ini adalah explanatori karena dilakukan dengan menguji hipotesis dari fenomena yang terjadi. Sehubungan Berkenaan dengan penelitian mengenai hubungan ketergantungan beberapa variabelvariabel dependen dan independen yang dianalisis, maka model yang digunakan adalah pendekatan Analisis Jalur (Path Analysis). dengan (3) Tiga Sub Struktural. Sebagaimana menurut Jonathan (2012;35).Populasi dari penelitian ini adalah Wajib Pajak orang Pribadi yang terdaftar di wilayah KPP Pratama Gambir Tiga yang terdaftar di 
Kanwil Jakarta Pusat yang telah menggunakan e-filing sebanyak 15.088 wajib pajak orang pribadi yang menggunakan $e$-filing. Penelitian ini menggunakan Variabel Independen Persepsi Kegunaan $\left(\mathrm{X}_{1}\right)$,Persepsi Kemudahan $\left(\mathrm{X}_{2}\right)$, Penggunaan e-filing $\left(\mathrm{Y}_{1}\right)$ sebagai variabel Intervening dan variabel dependen Kepatuhan Wajib Pajak $\left(\mathrm{Y}_{2}\right)$.

Ukuran sampel yang dibutuhkan untuk Analisis Jalur adalah diatas 100. Menurut Burhan $(2005 ; 105)$ Ukuran sampel akan dihitung dengan menggunakan rumus :

$$
\mathrm{n}=\frac{\mathrm{N}}{\mathrm{N}(\mathrm{d})^{2}+1}
$$

Keterangan :

$\mathrm{n} \quad=$ Jumlah Sampel yang dicari

$\mathrm{N} \quad=$ Jumlah populasi

$\mathrm{d} \quad=$ Nilai Presisi (ditentukan sebesar 0,1)

Persamaan Sub Strukturalnya dapat dirumuskan sebagai berikut :

Persamaan Sub Struktural 1: Y1 $=\mathrm{PY}_{1} \mathrm{X}_{1}+\mathrm{PY}_{1} \mathrm{X}_{2}+\mathrm{e}_{1}$

Persamaan Sub Struktural 2: $\mathrm{Y} 2=\mathrm{PY}_{2} \mathrm{Y}_{1}+\mathrm{e}_{2}$

Persamaan Sub Struktural 3: $\mathrm{Y} 3=\mathrm{PY}_{2} \mathrm{X}_{1}+\mathrm{PY}_{2} \mathrm{X}_{2}+\mathrm{e}_{1}$

\section{Operasionalisasi Variabel penelitian adalah sebagai berikut :}

Persepsi kegunaan $\left(\mathrm{X}_{1}\right)$ menurut Larasati (2013) seseorang percaya bahwa menggunakan suatu teknologi akan meningkatkan kinerjanya. Menurut Anggraeni (2015) Indikator persepsi kegunaan adalah Berguna,membantu melakukan pekerjaan lebih cepat. Persepsi kemudahan $\left(\mathrm{X}_{2}\right)$ Menurut larasati (2013) kepercayaan seseorang bahwa teknologi dapat dengan mudah untuk digunakan dan dipahami. Menurut Anggraeni (2015) Indikator Persepsi kemudahan adalah mudah dipelajari, mudah digunakan, mudah melakukan hal yang diinginkan dan mudah menjadi terampil. Pengguna $e$-filing $\left(\mathrm{Y}_{1}\right)$ Menurut Titis (2011) Pengguna untuk menggunakan $e$-filing ditentukan oleh minat dan minat itu sendiri dibentuk dari sikap dan norma subjektif. Menurut Anggraeni (2015) Indikator Niat untuk terus menggunakan dan memberikan rekomendasi kepada orang lain. Menurut Christian (2013) Kepatuhan WP $\left(\mathrm{Y}_{2}\right)$ adalah suatu keadaan di mana wajib pajak memenuhi kewajiban perpajakan secara sesuai dengan ketentuan dalam UndangUndang Perpajakan. Indikatornya menurut Rahayu (2010:139) adalah lengkap \& tepat waktu.

Adapun interpretasi dari hasil pengujian hipotesis disesuaikan dengan koefisien korelasi sebagai berikut : 
Kriteria Koefisien Korelasi

\begin{tabular}{|c|c|}
\hline Koefisien Korelasi (r) & Tingkat Hubungan \\
\hline $0-0,25$ & Korelasi sangat lemah \\
\hline $0,25-0,5$ & Korelasi cukup \\
\hline $0,5-0,75$ & Korelasi kuat \\
\hline $0,75-, 099$ & Korelasi sangat kuat \\
\hline 1 & Korelasi sempuma \\
\hline & \\
\hline (Sarwono,2012;201-202)
\end{tabular}

\section{HASIL DAN PEMBAHASAN}

\section{Uji Validitas}

Berdasarkan hasil tabel dibawah ini menunjukkan bahwa nilai $\mathrm{R}$ (hit) sama dengan atau lebih besar dari 0,098 berarti bahwa masing-masing variabel penelitian lolos uji validitas. Hasil ini sesuai dengan kriteria Sugiono (2016;333) dengan jumlah responden (N) sebesar 390 dan taraf signifikan 5\% maka nilai $\mathrm{R}$ (hit) sama dengan atau lebih besar dari 0,098 dan tidak boleh negatif ini berarti bahwa masing-masing variabel penelitian lolos uji validitas. Hal ini juga dapat dikatakan bahwa masing-masing konstruk dapat digunakan dalam penelitian ini.

\section{Uji Validitas}

\begin{tabular}{|l|c|c|}
\hline \multicolumn{1}{|c|}{ Variabel } & Signifikansi & Kesimpulan \\
\hline Persepsi Kegunaan (X1) & $>0,098$ & Valid \\
\hline Persepsi Kemudahan (X2) & $>0,098$ & Valid \\
\hline Penggunaan e-filing (Y1) & $>0,098$ & Valid \\
\hline Kepatuhan WP (Y2) & $>0,098$ & \\
\hline
\end{tabular}

Sumber : Hasil Olah Kuesioner SPSS 22,2017

\section{Uji Reliabilitas}

Hasil uji reliabilitas dengan menggunakan program SPSS 22 menunjukkan nilai Cronbach Alpha seluruh variabel penelitian lebih besar dari 0,70 . Hal ini berarti bahwa seluruh variabel penelitian dikatakan reliabel. Hasil ini sesuai dengan kriteria Ghozali $(2011 ; 47)$ Keandalan suatu konstruk dapat dinilai dari cronbach alpha. Apabila besarnya cronbach apha diatas 0,70 maka dapat dikatakan Reliabel. Berdasarkan Hasil pengujian reliabilitas dari masing-masing variabel sebagai berikut : a. Variabel $\mathrm{X}_{1}$ sebesar 0,80; b.Variabel $\mathrm{X}_{2}$ sebesar 0,80; c.Variabel $\mathrm{Y}_{1}$ sebesar 0,81; dan variabel $\mathrm{Y}_{2}$ sebesar 0,81. Dengan demikian keempat variabel tersebut realibel karena, nilai reabilitasnya $>0,70$.

\section{Uji Asumsi Klasik}

\section{Uji Normalitas}

Berdasarkan hasil uji normalitas dengan metode Kolmogorov Smirnov menunjukkan nilai test statistic 0,039 dan nilai Asymp. Sig menunjukkan nilai 0,184 > 0,05. Dengan demikian memenuhi kriteria pengujian di atas ( nilai $p$-value > level of significant $(0,05)$, sehingga dapat disimpulkan bahwa data berdistribusi normal.

\section{Uji Multikolineitas}


Berdasarkan tabel diatas korelasi antar variabel $\mathrm{X}_{1}$ dan $\mathrm{X}_{2}$ tidak tinggi, yaitu Korelasi antara variabel $\mathrm{X}_{1}$ dan $\mathrm{X}_{2}$ sebesar 0,524. Maka kesimpulannya tidak terjadi Multikolinieritas antara variabel independen yang digunakan dalam model regresi ini. Korelasi Sebesar 0,524 mempunyai arti hubungan antar variabel independen korelasi kuat dan searah. Sarwono $(2012 ; 92)$

\section{Uji Hipotesis}

\section{Hasil koefisien jalur sub struktur 1}

Berdasarkan hasil penghitungan untuk substruktur 1 dengan nilai signifikansi untuk variabel $\mathrm{X}_{1}$ sebesar $0,000<$ dari 0,05 dan $X_{2}$ sebesar $0,000<$ dari 0,05. Dengan demikian $X_{1}$ dan $X_{2}$ mempengaruhi $\mathrm{Y}_{1}$ secara signifikan. Besarnya pengaruh $\mathrm{X}_{1}$ terhadap $\mathrm{Y}_{1}$ sebesar 0,235 , Besarnya pengaruh $\mathrm{X}_{2}$ terhadap $\mathrm{Y}_{1}$ sebesar 0,350 .

Besarnya nilai $\mathrm{R}$ square $\left(\mathrm{R}^{2}\right)$ pada tabel Model Summary adalah 0,263 ini menunjukkan bahwa pengaruh $\mathrm{X}_{1}$ dan $\mathrm{X}_{2}$ terhadap $\mathrm{Y}_{1}$ adalah sebesar $26,30 \%$ sementara sisanya $73,70 \%$ adalah variabel lainnya seperti pengetahuan yang tidak dimasukkan dalam penelitian ini.

Hasil pengujian Hipotesis pertama dengan nilai Probabilitas (Sig.) sebesar 0,00<0,05 maka H0 ditolak dan Ha diterima dengan demikan Persepsi Kegunaan $\left(\mathrm{X}_{1}\right)$ berpengaruh Signifikan terhadap Penggunaan $e$-filing $\left(\mathrm{Y}_{1}\right)$.

Hasil pengujian Hipotesis Kedua dengan nilai Probabilitas (Sig.) sebesar 0,00<0,05 maka H0 ditolak dan $\mathrm{Ha}$ diterima dengan demikan Persepsi Kemudahan $\left(\mathrm{X}_{2}\right)$ berpengaruh Signifikan terhadap Penggunaan $e$-filing $\left(\mathrm{Y}_{1}\right)$.

\section{Hasil koefisien sub struktur 2}

Berdasarkan hasil penghitungan untuk substruktur 2 dengan nilai signifikansi untuk variabel $\mathrm{Y}_{1}$ sebesar $0,000<$ dari 0,05 dan $\mathrm{Y}_{2}$ sebesar $0,000<0,05$. Dengan demikian $\mathrm{Y}_{1}$ mempengaruhi $\mathrm{Y}_{2}$ secara signifikan. Besarnya pengaruh $\mathrm{Y}_{1}$ terhadap $\mathrm{Y}_{2}$ sebesar 0,395,

Besarnya nilai $\mathrm{R}$ square $\left(\mathrm{R}^{2}\right)$ pada tabel Model Summary adalah 0,156 ini menunjukkan bahwa pengaruh $\mathrm{Y}_{1}$ mempengaruhi $\mathrm{Y}_{2}$ sebesar $15,6 \%$ sementara sisanya $75,40 \%$ adalah variabel lainnya yang tidak dimasukkan dalam penelitian ini.

\section{Hasil koefisien jalur sub struktur 3}

Berdasarkan hasil penghitungan untuk substruktur 3 dengan nilai signifikansi untuk variabel $\mathrm{X}_{1}$ ke $\mathrm{Y}_{2}$ sebesar $0,000_{1}<$ dari 0,05 dan $\mathrm{X}_{2} \mathrm{ke} \mathrm{Y}_{2}$ sebesar 0,000<0,05. Dengan demikian $\mathrm{X}_{1}$ dan $\mathrm{X}_{2}$ mempengaruhi $\mathrm{Y}_{2}$ secara signifikan. Besarnya pengaruh $\mathrm{X}_{1}$ terhadap $\mathrm{Y}_{2}$ sebesar 0,299, Besarnya pengaruh $\mathrm{X}_{2}$ terhadap $\mathrm{Y}_{2}$ sebesar 0,256 .

Besarnya nilai $\mathrm{R}$ square $\left(\mathrm{R}^{2}\right)$ pada tabel Model Summary adalah 0,235 ini menunjukkan bahwa pengaruh $\mathrm{X}_{1}$ dan $\mathrm{X}_{2}$ terhadap $\mathrm{Y}_{2}$ adalah sebesar $23,50 \%$ sementara sisanya $67,50 \%$ adalah variabel lainnya yang tidak dimasukkan dalam penelitian ini.

$\mathrm{Uji}_{4}$ Coeffisien, nilai signifikan dari $\mathrm{X}_{1}=0,000$ dan $\mathrm{X}_{2}=0,000$ lebih kecil dari 0,05. Sehingga kesimpulannya variabel $\mathrm{X}_{1}$ dan $\mathrm{X}_{2}$ berpengaruh signifikan terhadap $\mathrm{Y}_{2}$. Besarnya $\mathrm{R}$ square (R2) pada tabel Model Summary adalah 0,235 ini menunjukkan $\mathrm{H}_{5}$ pengaruh $\mathrm{X}_{1}$ dan $\mathrm{X}_{2}$ terhadap $\mathrm{Y}_{2}$ adalah sebesar $23,50 \%$ sementara sisanya $76,50 \%$ adalah variabel lain yang tidak dimasukkan dalam penelitian ini. Sedangkan untuk $e_{3}$ didapat dari rumus $e_{3}=\sqrt{ }(1-0,235)=0,485$.

\section{Hasil uji hipotesis secara simultan (Uji F)}


Dari tabel ANOVA pada sub struktural 1, dalam hubungan antara variabel Persepsi Kegunaan, Persepsi Kemudahan terhadap Penggunaan $e$-filing menghasilkan nilai $\mathrm{F}=69,217$ dengan nilai Probabilitas (Sig.) $=0,00<0,05$.

Sub struktural 2 diperoleh nilai F sebesar 71,866 dengan nilai Probabilitas (Sig.) $=0,00<0,05$ Dan dengan nilai Probabilitas (Sig.) $=0,00<0,05$

maka Ho ditolak dan Ha diterima, artinya artinya $X_{1}$ dan $X_{2}$ secara simultan berpengaruh secara signifikan terhadap Penggunaan e-filing ( $\mathrm{Y}_{1}$ ). Sub struktural 3 diperoleh nilai $\mathrm{F}$ sebesar 59,572 maka Ho ditolak dan Ha diterima, artinya signifikan artinya signifikan terhadap Kepatuhan WP $\left(\mathrm{Y}_{2}\right)$ dengan nilai Probabilitas (Sig. $)=0,00<0,05$

\section{Besarnya Pengaruh Langsung}

Besarnya pengaruh langsung dari variabel $\mathrm{X}_{1}$ dan $\mathrm{X}_{2}$ ke $\mathrm{Y}_{1}$; dari $\mathrm{X}_{1}$ dan $\mathrm{X}_{2}$ ke $\mathrm{Y}_{2}$; dan dari $\mathrm{Y}_{1}$ ke $\mathrm{Y}_{2}$ adalah sebagai berikut:

- Pengaruh variabel Persepsi Kegunaan terhadap Penggunaan e-filing sebesar 0,235

- Pengaruh variabel Persepsi Kemudahan terhadap Penggunaan e-filing sebesar 0,350

- Pengaruh variabel Penggunaan $e$-filing terhadap Kepatuhan wajib pajak sebesar 0,395

- Pengaruh variabel Persepsi Kegunaan terhadap kepatuhan wajib pajak sebesar 0,299

- Pengaruh variabel Persepsi kemudahan terhadap Kepatuhan wajib pajak sebesar 0,256

\section{Besarnya Pengaruh Tidak Langsung}

Besarnya pengaruh tidak langsung dari variabel $X_{1}$ ke $Y_{2}$ melalui $Y_{1}$ dan $X_{2}$ ke $Y_{2}$ melalui $Y_{1}$ adalah sebagai berikut:

- Pengaruh variabel Persepsi Kegunaan $\left(\mathrm{X}_{1}\right)$ terhadap kepatuhan wp melalui Penggunaan e-filing sebesar 0,093

- Pengaruh variabel Persepsi Kemudahan terhadap kepatuhan wp melalui Penggunaan $e$ filing sebesar 0,138

\section{Besarnya Pengaruh Total}

Besarnya pengaruh langsung dari variabel $X_{1}$ ke $Y_{2}$ melalui $Y_{1}$ dan dari variabel $X_{1}$ ke $Y_{2}$ melalui $\mathrm{Y}_{1}$

- Pengaruh variabel Persepsi Kegunaan terhadap kepatuhan wp melalui Penggunaan $e$ filing sebesar 0,630

- Pengaruh variabel Persepsi Kegunaan terhadap kepatuhan wp melalui Penggunaan $e$ filing sebesar 0,745

Nilai koefisien jalur untuk model riset diatas tertera pada diagram jalur dibawah ini:

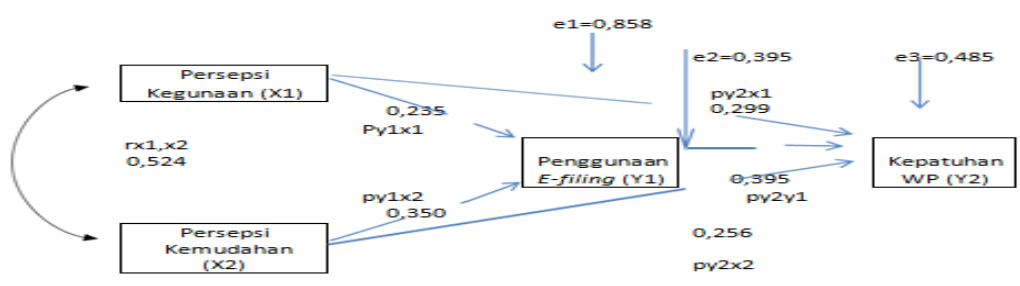

Gambar 2.Diagram Jalur dengan Nilai Koefesien Jalurnya

Diagram jalur pada gambar diatas mempunyai persamaan struktural sebagai berikut:

Sub Struktural 1: $\mathrm{Y}_{1}=0,235 \mathrm{X}_{1}+0,350 \mathrm{X}_{2}+\mathrm{e}_{1}$

Sub Struktural 2: $\mathrm{Y}_{2}=0,395+\mathrm{e}_{2}$

Sub Struktural $3: Y_{2}=0,299 X_{1}+0,256 X_{2}+e_{3}$ 
Dengan demikan hasil Analisis diatas dapat diringkas sebagai berikut :

Sub Struktural 1 : Pengaruh Persepsi Kegunaan terhadap penggunaan e-filing secara langsung sebesar 0,585. Sub Struktural 2 : Pengaruh Persepsi Kemudahan terhadap penggunaan $e$-filing secara langsung sebesar 0,585. Sub Struktural 3: Pengaruh Penggunaan e-filing terhadap Kepatuhan WP secara langsung sebesar 0,395.

Berdasarkan Hasil Analisis diatas memberikan ringkasan sebagai berikut :

Pengaruh variabel Persepsi Kegunaan terhadap Penggunaan $e$-filing sebesar 0,235

Pengaruh variabel Persepsi Kemudahan terhadap Penggunaan $e$-fling sebesar 0,350

Pengaruh variabel Penggunaan e-filing terhadap Kepatuhan wajib pajak sebesar 0,395

Pengaruh variabel Persepsi Kegunaan terhadap kepatuhan wajib pajak 0,299

Pengaruh variabel Persepsi kemudahan terhadap Kepatuhan wajib pajak 0,256

Pengaruh variabel Persepsi Kegunaan terhadap kepatuhan wp melalui Penggunaan $e$-filing 0,093

Pengaruh variabel Persepsi Kemudahan terhadap kepatuhan wp melalui Penggunaan $e$-filing 0,138

\section{KESIMPULAN DAN SARAN \\ Kesimpulan}

Secara keseluruhan model konseptual persamaan sub struktural 1 yang dirancang untuk menguji pengaruh variabel-variabel Persepsi Kegunaan terhadap penggunaan e-filing secara 1 langsung dan persamaan sub struktur 2 untuk menguji pengaruh variabel Persepsi Kemudahan terhadap penggunaan $e$-filing secara langsung dan persamaan sub struktur 2 untuk menguji pengaruh variable Pengaruh Penggunaan $e$-filing terhadap Kepatuhan WP secara langsung telah memenuhi kelayakan model berdasarkan asumsi klasik berupa pengujian normalitas dan multikolinearitas yang didahului pengujian validitas dan reliabilitas masing-masing pertanyaan dari variable penelitian. Artinya kondisi hasil pengujian berdasarkan data kuesioner dari WP, telah menggambarkan kondisi empiris dalam kondisi masyarakat secara nyata.

\section{Saran}

Peneliti menyarankan agar peneliti selanjutnya tidak hanya meneliti variabel tentang persepsi kegunaan dan kemudahan terhadap penggunaan e-filing ,akan tetapi juga merupakan peranan yang penting dalam mempengaruhi niat WP untuk menggunakan sistem e-filing. Jika WP mendengarkan saran dari orang lain untuk menggunkan sistem e-filing, ia akan berniat menggunakan sistem e-filing. Dan menambah jumlah sampel dan memperluas lokasi pengambilan sampel tidak hanya di KPP Gambir Tiga Saja. Sehingga hasil yang didapat juga akan lebih maksimal.

\section{REFERENSI}

Ajzen, I., \& Fishbein, M., (1975), Belief, Attitude, Intention, and Behavior: An Introduction to Theory and Research, 129-385, Addison-Wesley, Reading, MA

Agarwal, R. and Prasad, J. (1999) Are Individual Differences Germane to the Acceptance of New Information Technologies? Decision Sciences, 30, 361-392. http://dx.doi.org/10.1111/j.1540-5915.1999.tb01614.x diakses pada Selasa, 09 Maret 2017 Pukul 18.00 WIB 
Anggraini, Rila (2015). Pengaruh Persepsi Kemudahan Penggunaan dan Persepsi Kegunaan Terhadap Niat Untuk Menggunakan dan Penggunaan Aktual Layanan Jejaring Sosial Berbasis Lokasi (Studi pada Mahasiswa Fakultas Ekonomi dan Bisnis Universitas Brawijaya Malang). Jurnal Ekonomi dan Bisnis. Vol 20 (1) 1 - 52

Bhatti, T. (2007) Exploring Factors Influencing the Adoption of Mobile Commerce. Journal of Internet Banking and Commerce. http://www.icommercecentral.com/openaccess/exploring-factors-influencing-the-adoption-of-mobile-commerce.php?aid=38513 diakses pada Selasa, 09 Maret 2017 Pukul 18.00 WIB

Davis, F. D. (1989), "Perceived usefulness, perceived ease of use, and user acceptance of information technology", MIS Quarterly, 13 (3): 319-340

Davis, F. D.; Bagozzi, R. P.; Warshaw, P. R. (1989), "User acceptance of computer technology: A comparison of two theoretical models", Management Science, 35: 982-1003

Esy Desmayanti, Zulaikha (2012) Faktor-faktor yang mempengaruhi penggunaan fasilitas efilling oleh wajib pajak sebagai sarana penyampaian SPT masa secara ONLINE DAN REALTIME (Kajian Empiris di Wilayah Kota Semarang)

Endang Fatmawati (2015) Technology Acceptance Model (TAM) untuk menganalisis penerimaan terhadap sistem informasi perpustakaan Jurnal Iqra' Volume 09 No.01 Mei, 2015

Eugenia Sareba' Sesa, Vierly Ananta Upa, Josephine K. Tjahjono (2015) Pengaruh Persepsi Wajib Pajak Orang Pribadi Pada Penerapan e-filing Terhadap Kepatuhan Dalam Menyampaikan Spt Tahunan Di Kota Surabaya (Jurnal GEMA AKTUALITA, Vol. 4 No. 1, Juni 2015)

Galuh Ratih Larasati (2013) Pengaruh Persepsi Kegunaan, Persepsi Kemudahan, dan Keberhasilan Diri Atas Penggunaan Komputer Terhadap Minat Pemanfaatan Aplikasi SIMDA Keuangan (Studi Kasus pada Pemerintah Daerah Kabupaten Mojokerto)

Kismantoro Petrus (2014) E-filing - SPT Online?. https://finance.detik.com/ekonomibisnis/2524458/dari-24-juta-wajib-pajak-baru-150-ribu-yang-pakai-spt-online diakses pada kamis,16 maret 2017 Pukul 19:08 WIB

Kolompoy, Calvin, Ventje Ilat, and Harijanto Sabijono (2015) "Pengaruh Perilaku Individu Wajib Pajak Orang Pribadi Terhadap Penggunaan E-filing di Kota Manado." ACCOUNTABILITY 4.2.

Lai Ming Ling \& Choong Kwai Fatt , (2008) Electronic Tax Filing System: Taxpayers' Perspectives. Seventh Wuhan International Conference on EBusiness:Unlocking The Full Potential of Global Technology, 2008, Volume 1, pp.338-343

Maria Imelda Claudia (2015) Pengaruh Persepsi Kemudahan dan Kepuasan Wajib Pajak Terhadap Penggunaan E-filing (Survei Pada Wajib Pajak Orang Pribadi di KPP Pratama Majalaya)

Mujiyati ${ }^{1}$, et.al (2015) Faktor-Faktor yang mempengaruhi pengguanan e-filing bagi wajib pajak orang pribadi (Studi empiris pada wajib pajak di KPP Sukoharjo dan KPP Surakarta) ISSN 2460-0784

Nurul Citra Noviandini (2012) Pengaruh persepsi kebermanfaatan ,persepsi kemudahan penggunaan dan kepuasan wajib pajak terhadap penggunaan e-filling bagi wajib pajak di Yogyakarta. 
Oktavia Bella Ayu ( 2013) Pengaruh penggunaan Sistem e-filing terhadap tingkat kepatuhan Wajib Pajak dengan Pemahaman internet sebgai Variabel Moderasi (Studi pada KP2KP. Mahasiswa Program Studi akuntansi universitas Muhammadiyah Jember.

Risal C.Y. Laihad (2013) Pengaruh Perliaku wajib pajak terhadap Penggunaan e-filling wajib pajak dikota Manado. Jurnal EMBA Vol.1 No.3 September 2013,Hal 44-51

Siti Kurnia Rahayu (2010) .PERPAJAKAN INDONESIA : Konsep dan Aspek Formal, Yogyakarta : Graha Ilmu.

Suherman Maman,Medina Almunawwaroh (2015) Pengaruh Penerapan e-filing terhadap kepatuhan wajib pajak dalam penyampaian surat pemberitahuan (SPT) Tahunan pada kantor pelayanan Pajak Pratama Kota Tasikmalaya

Winna Titis Sugihanti (2011) Analisis Faktor-faktor yang mempengaruhi minat perilaku wajib pajak untuk menggunakan e-filling (Studi Empiris Pada Wajib Pajak Badan Kota Semarang) Universitas Diponegoro

http://www.ddtc.co.id/upload/pdf/document-rp-per-01-pj-2017.pdf diakses pada Rabu,14Juni 2017 Pukul 18:26 WIB 